\title{
Effect of Different Packaging Conditions on Shelf Life of Chicken Samosa Stored at Refrigeration Temperature
}

\author{
Bhaskar Kanchi, Anitha Reddy Nalla*, Naveen Kumar Reddy Metla, \\ Shashi Kumar Manyam and Kesava Rao Vadapu
}

\author{
Department of Livestock Products Technology, C.V.Sc, PVNR TVU, Hyderabad, India \\ *Corresponding author
}

\begin{tabular}{|c|c|}
\hline & A B S T R A $\mathbf{C}$ \\
\hline $\begin{array}{l}\text { Chicken samosa, } \\
\text { Shelf life, } \\
\text { Vacuum } \\
\text { packaging, } \\
\text { Aerobic } \\
\text { packaging }\end{array}$ & \multirow{3}{*}{$\begin{array}{l}\text { The present study was conducted to evaluate the shelf life of chicken samosa prepared } \\
\text { using broiler chicken (aged } 8 \text { weeks). The recipe for chicken samosa was standardized and } \\
\text { the product was packed in LDPE under vacuum (VP) and aerobic (AP) packaging } \\
\text { conditions and stored at } 4 \pm 1^{\circ} \mathrm{C} \text {.Physico-chemical, microbiological and sensory evaluation } \\
\text { was studied on } 1,3 \text { and } 6 \text { days of storage. The storage period brought about significant } \\
\text { changes in pH, TBA value, total plate count (TPC) in chicken samosa packed under } \\
\text { different packaging systems. The pH was found higher in vacuum packed chicken samosa } \\
\text { compared to aerobic package. Total plate count values were significantly (P<0.05) lower } \\
\text { in vacuum packed chicken samosas. TBA values were found higher in aerobically } \\
\text { packaged samosa. The sensory scores of vacuum packed samosa had higher scores for } \\
\text { appearance, flavor and overall acceptability when compared with aerobically packed } \\
\text { samosa. In conclusion, both AP and VP packed chicken samosa can be stored for about } 6 \\
\text { days at refrigerated storage without much noticeable changes. }\end{array}$} \\
\hline Article Info & \\
\hline $\begin{array}{l}\text { Accepted: } \\
25 \text { April } 2017 \\
\text { Available Online: } \\
10 \text { May } 2017\end{array}$ & \\
\hline
\end{tabular}

\section{Introduction}

India with annual production of 2.2 million tons of poultry meat shares $2.44 \%$ of the total poultry meat produced around the world (Kulkarni and Naveena, 2013). The market of processed meat is just $4-5 \%$ of the total chicken consumption in India. So, processing of chicken is essential to exploit its undermined potential and can provide tasty, convenience and designer products to nonvegetarians. Traditional meat products are highly relished in all countries of Asia, Africa, Australia, Europe and South America. Chicken samosa is an indigenous and delicious meat product of India prepared by cooking comminuted meat with spices and seasonings. Due to great regional diversity, this product display variations in processing method and sensory quality. Although increasing urbanization and change in lifestyle have changed in the past few years, the liking for traditional meat products still exists among people. Traditional Indian meat based foods require many preparatory steps and longer preparation time. In order to minimize such burden of processing in the kitchen and to cater for the needs of the increasing working population, the demand for ready-to-eat meat products is growing in Indian and overseas markets. Value added poultry meat products are being produced by 
some processors and marketed under different brand names with have high consumer acceptance.

The present study includes standardization of recipe, profit evaluation, proximate composition and quality evaluation of chicken samosa at aerobic and vacuum packaging under refrigeration storage.

\section{Materials and Methods}

\section{Meat source}

Broiler chicken $(n=6)$ of about eight weeks age were obtained from local retail meat shop, brought to Department of Livestock Products Technology and hygienically slaughtered using standard procedure. Dressed carcasses were hand deboned within one hour of slaughter. The deboned chicken meat were packed in low-density polyethylene (LDPE) and stored at $-20 \pm 2^{\circ} \mathrm{C}$ till further use.

\section{Preparation of chicken samosa}

Formulation of chicken samosa is showed in table 1. Partially thawed meat was minced using automatic meat mincer by passing through $4 \mathrm{~mm}$ plates (Talleres Ramon Make P-22, Barcelona).The minced meat was pressure cooked for 3 whistles. Cumin, mustard, curry leaves, finely chopped onion, ginger garlic paste, turmeric and garam masala were fried in oil in sequence until the raw flavor vanishes, then cooked meat was added. Later salt, chilli powder were added, finally chopped coriander was added. About $20 \mathrm{~g}$ of samosa stuff is placed in ready to use samosa sheets (Switz Company, measured about 10.6 x 2.7 inch size and weighed $10 \mathrm{~g}$ ) and shaped into regular triangle samosa. Those filled samosas were fried in hot oil at $180^{\circ} \mathrm{Cuntil}$ they turns golden brown colour. Prepared samosas were packed under Aerobic and vacuum conditions in LDPE packaging material and stored at refrigeration for further analysis.

\section{Analyses of packed chicken samosa}

Chicken samosas were examined for changes in physico-chemical, microbiological and sensory parameters during 1,3 , and 6 days of storage. Each time three samples from each treatment were randomly taken out. Samples were taken for microbiological examination first, followed by physico-chemical parameters. Remaining parts of samples were used for sensory examination. Evaluation of quality of chicken samosas was done from the next day of preparation.

\section{Estimation of pH}

Estimation of $\mathrm{pH}$ was measured by adopting the procedure laid down by AOAC using digital $\mathrm{pH}$ meter (Elico model L 1-10 T, Chennai) with a glass probe electrode. About $10 \mathrm{~g}$ of sample from each aerobic and vacuum packed samosas was blended with $50 \mathrm{ml}$ of distilled water for one minute in a blender and the volume was made up to $100 \mathrm{ml}$ and $\mathrm{pH}$ was recorded.

\section{Estimation of proximate composition}

The percentage of moisture, protein, fat and total ash were determined as per the methods recommended by A.O.A.C. (1984). Dry matter content was determined by ovendrying at $103^{\circ} \mathrm{C}$; total fat content was obtained by Soxhlet extraction using petroleum ether (B.P. $80-90^{\circ} \mathrm{c}$ ); Ash content was determined by charring fresh sample followed by heating in a muffle furnace for 3 to $5 \mathrm{~h}$ at $600^{\circ} \mathrm{c}$; Kjeldahal method was used for the analysis of total nitrogen content and crude protein content was calculated and expressed as percentage. Carbohydrate content was estimated by using the following formula. 
Carbohydrate $\quad(\%)=100 \%-\% \quad($ Moisture + Ash + Crude protein + Crude fat $)$

\section{Sensory evaluation}

The organoleptic attributes viz. colour, flavour, juiciness and tenderness of chicken samosa were assessed by subjecting to a semitrained five-member taste panel drawn from the staff of the College of Veterinary Science, Hyderabad. Aerobic and vacuum packed samosas were served to the taste panel members as randomly coded samples and the panelists were provided with a nine point Hedonic score card to assess the colour, flavour, juiciness and tenderness of the sample.

\section{Results and Discussion}

Proximate composition and cost of
production

The results (Table 2) revealed the proximate composition of chicken samosas, these results are corroborated with the findings of Muthulakshmi et al., (2015) who studied the proximate composition of samosa prepared from spent hen meat emulsion. The cost of production of one samosa (Table 3) was 8.55 Rupees.
pH: The VP chicken samosas revealed a bit higher $\mathrm{pH}$ (Table 4) than AP chicken samosa, this is in agreement with Muthulakshmi et al., (2015) who studied the shelf life of samosa utilizing spent hen meat emulsion. Babji et al., (2000) also reported that $\mathrm{pH}$ of vacuumpacked goat meat mince increased from 6.00 on day 7 to 6.10 on day 28 of refrigerated storage. Similar findings also reported by Geetha Chauhan et al., (2003) who made samosas from spent hen frames meat.

\section{TBA}

Significantly $(\mathrm{P}<0.05)$ lower TBA values were observed (Table 4) in VP chicken samosa compared to AP chicken samosa. Similar findings were reported by various workers (Salahuddin et al., 1989; Geetha Chauhan et al., 2003 and Muthulakshmi et al., 2009). The higher fat content might be the reason for higher TBA values in the samosas, which is similar to TBA values for vacuumpacked ground beef patties (Maca et al., 1997). Significant $(\mathrm{P}<0.05)$ interactive effect between treatment and storage period was observed in case of TBA value and as the storage period advanced TBA values in chicken samosa increased.

Table.1 Formulation of Chicken samosa

\begin{tabular}{|c|c|}
\hline Ingredients & Quantity (\%) \\
\hline Minced Chicken meat & 58.3 \\
\hline Onion & 29.6 \\
\hline Oil & 6.5 \\
\hline Salt & 2.6 \\
\hline Ginger garlic paste & 2.6 \\
\hline Chilli powder & 1.3 \\
\hline Garam Masala & 0.3 \\
\hline Turmeric & 0.05 \\
\hline Mustard & 0.08 \\
\hline Cumin & 0.07 \\
\hline Curry leaves \& coriander leaves & 0.3 \\
\hline
\end{tabular}


Table.2 Proximate composition of Chicken samosa

\begin{tabular}{|c|c|}
\hline Component & Percentage \\
\hline Moisture & 43.53 \\
\hline Crude Protein & 20.37 \\
\hline Total Carbohydrate & 23.00 \\
\hline Crude Fat & 12.90 \\
\hline Total Ash & 0.20 \\
\hline
\end{tabular}

Table.3 Cost of production of chicken samosa with one $\mathrm{kg}$ bone less chicken

\begin{tabular}{|c|c|c|}
\hline S. No: & Ingredients & Cost in Rupees \\
\hline $\mathbf{1}$ & Chicken Meat & 260.00 \\
\hline $\mathbf{2}$ & Onion & 5.00 \\
\hline $\mathbf{3}$ & Oil & 80.00 \\
\hline $\mathbf{4}$ & Ready to use samosa sheets & 79.50 \\
\hline $\mathbf{5}$ & Garlic & 3.15 \\
\hline $\mathbf{6}$ & Ginger & 4.05 \\
\hline $\mathbf{7}$ & Red chilli powder & 3.49 \\
\hline $\mathbf{8}$ & Garam masala(Dry spice mix) & 4.50 \\
\hline $\mathbf{9}$ & Turmeric & 0.03 \\
\hline $\mathbf{1 0}$ & Mustard & 0.25 \\
\hline $\mathbf{1 1}$ & Cumin & 0.35 \\
\hline $\mathbf{1 2}$ & Coriander and curry leaves & 3.00 \\
\hline $\mathbf{1 3}$ & Miscellaneous & 10.00 \\
\hline $\mathbf{1 4}$ & Yield (number) & 53.00 \\
\hline $\mathbf{1 5}$ & Cost (per samosa) & 8.55 \\
\hline
\end{tabular}

Table.4 Effect of different packaging conditions on physico-chemical and microbiological properties of chicken samosa

\begin{tabular}{|c|c|c|c|}
\hline Days & $\mathbf{1}$ & $\mathbf{3}$ & $\mathbf{6}$ \\
\hline \multicolumn{5}{|c|}{$\boldsymbol{p H}$} \\
\hline AP & $5.19 \pm 0.04^{\mathrm{cA}}$ & $5.94 \pm 0.01^{\mathrm{bA}}$ & $6.02 \pm 0.03^{\mathrm{aA}}$ \\
\hline VP & $5.43 \pm 0.01^{\mathrm{cB}}$ & $5.98 \pm 0.06^{\mathrm{bA}}$ & $6.07 \pm 0.07^{\mathrm{aA}}$ \\
\hline \multicolumn{5}{|c|}{$\boldsymbol{T B A}$ Value $(\boldsymbol{m g}$ Malonaldehyde $/ \boldsymbol{k g})$} \\
\hline AP & $0.39 \pm 0.16^{\mathrm{cA}}$ & $0.56 \pm 0.01^{\mathrm{bA}}$ & $1.07 \pm 0.12^{\mathrm{aA}}$ \\
\hline VP & $0.33 \pm 0.20^{\mathrm{cB}}$ & $0.53 \pm 0.13^{\mathrm{bA}}$ & $0.84 \pm 0.08^{\mathrm{aB}}$ \\
\hline \multicolumn{5}{|c|}{ Total plate count $(\boldsymbol{l o g} \boldsymbol{C F U} / \boldsymbol{g})$} \\
\hline AP & $1.88 \pm 0.04^{\mathrm{cA}}$ & $2.36 \pm 0.01^{\mathrm{bA}}$ & $2.88 \pm 0.06^{\mathrm{aA}}$ \\
\hline VP & $1.63 \pm 0.04^{\mathrm{cB}}$ & $1.85 \pm 0.04^{\mathrm{bB}}$ & $2.03 \pm 0.08^{\mathrm{aB}}$ \\
\hline
\end{tabular}

Values are Mean \pm SE; $(n=6)$. Means with different superscripts in a row (lower case letters) and in a column (upper case letters) differ significantly $(\mathrm{P}<0.05)$. 
Table.5 Effect of different packaging conditions on sensory attributes of chicken samosa

\begin{tabular}{|c|c|c|c|}
\hline Days & $\mathbf{1}$ & $\mathbf{3}$ & $\mathbf{6}$ \\
\hline \multicolumn{5}{|c|}{ Appearance } \\
\hline AP & $6.81 \pm 0.55^{\mathrm{aA}}$ & $6.54 \pm 1.15^{\mathrm{bB}}$ & $6.32 \pm 1.47^{\mathrm{cB}}$ \\
\hline VP & $6.80 \pm 1.05^{\mathrm{aA}}$ & $6.66 \pm 1.21^{\mathrm{bA}}$ & $6.57 \pm 1.05^{\mathrm{CA}}$ \\
\hline \multicolumn{4}{|c|}{ Flavour } \\
\hline AP & $6.70 \pm 1.15^{\mathrm{aB}}$ & $6.67 \pm 1.10^{\mathrm{bA}}$ & $6.53 \pm 1.18^{\mathrm{cA}}$ \\
\hline VP & $6.86 \pm 0.82^{\mathrm{aA}}$ & $6.50 \pm 0.76^{\mathrm{bB}}$ & $6.47 \pm 1.03^{\mathrm{CB}}$ \\
\hline \multicolumn{4}{|c|}{ Juiciness } \\
\hline AP & $7.62 \pm 1.43^{\mathrm{aB}}$ & $7.47 \pm 0.78^{\mathrm{bB}}$ & $7.33 \pm 0.35^{\mathrm{CB}}$ \\
\hline VP & $7.87 \pm 1.65^{\mathrm{aA}}$ & $7.67 \pm 1.05^{\mathrm{bA}}$ & $7.51 \pm 0.76^{\mathrm{CA}}$ \\
\hline \multicolumn{4}{|c|}{ Texture } \\
\hline AP & $7.17 \pm 1.18^{\mathrm{aA}}$ & $6.90 \pm 1.64^{\mathrm{bB}}$ & $6.72 \pm 1.75^{\mathrm{CB}}$ \\
\hline VP & $7.07 \pm 1.23^{\mathrm{aB}}$ & $6.97 \pm 1.04^{\mathrm{bA}}$ & $6.77 \pm 0.86^{\mathrm{CA}}$ \\
\hline \multicolumn{4}{|c|}{ Overall Acceptability } \\
\hline AP & $7.37 \pm 1.23^{\mathrm{aB}}$ & $7.07 \pm 1.82^{\mathrm{bB}}$ & $6.83 \pm 1.76^{\mathrm{CB}}$ \\
\hline VP & $7.40 \pm 1.86^{\mathrm{Aa}}$ & $7.14 \pm 0.69^{\mathrm{bA}}$ & $6.92 \pm 1.81^{\mathrm{cA}}$ \\
\hline
\end{tabular}

Values are Mean \pm SE; $(n=6)$. Means with different superscripts in a row (lower case letters) and in a column (upper case letters) differ significantly $(\mathrm{P}<0.05)$.

\section{Microbiological evaluation}

Microbial counts were influenced (Table 4) significantly $(\mathrm{P}<0.05)$ by storage period and method of packaging. The SPC counts were well within the limits of $\log 6.0 \mathrm{CFU} / \mathrm{g}$ prescribed for cooked meat products (Shapton and Shapton, 1991). Similar trend was observed by Muthulakshmi et al., (2015) and Maca et al., (1997).

\section{Sensory evaluation}

Sensory scores of chicken samosas both (VP) and (AP) are presented in table 5. Over all acceptability scores were significantly $(\mathrm{P}<0.05)$ differed between AP and VP samosas. VP samosa showed higher scores than AP samosas. Organoleptic quality found to be reduced with storage period (from 1 to 6 days) but the samosas are acceptable at 6 day without having appreciable changes.

In conclusion, from above study it was concluded that acceptable quality samosas could be prepared from chicken meat and they could be stored in Vacuum packaging, during storage under refrigeration. Vacuum packaging improved the oxidative stability as indicated by low TBA number. Both AP and VP chicken samosas are acceptable and can be stored for 6 days under refrigeration storage. Vacuum packaging had definite advantage in preserving the sensory quality of chicken samosa when compared with aerobic packaging.

\section{Acknowledgments}

The Associate Dean, College of Veterinary Science, Rajendranagar, Hyderabad is duly acknowledged for providing necessary financial and infrastructure facilities for this study.

\section{References}

AOAC. 1984. Official methods of analysis. 14th edition. Association of Official 
Analytical Chemists, Arlington, Virginia, USA.

Babji, Y., Murthy, T. R. K. and Anjaneyulu, A. S. R. 2000. Microbial and sensory quality changes in refrigerated minced goat meat stored under vacuum and in air. Small Rumin. Res. 36:75-85.

Geetha Chauhan, Kondaiah, N., Anjaneyulu, A.S.R., Mendiratta, S.K. and Keshri, R.C.2003. Studies on development of chicken samosa from cooked meat of spent hen frames. Indian J. Meat Sci., 1: 30-33.

Kulkarni, V. V. and B. M. Naveena. (2013) Poultry meat industry: An overview on safe food production. Processing of XXX conference and National Symposium of Indian poultry sciences association. 14-15.

Maca, J.V., Miller, R. K. and Acuff, G. R.1997. Microbiological, sensory and chemical characteristics of vacuum- packed ground beef patties treated with salts of organic acids. J. Food Sci. 62:591-596.

Muthulakshmi, M., Dushyanthan, K., Venkataramanujam, V., and Vasanthi, C.2009.

Physico-chemical and microbiological qualities of buffalo meat sausages incorporating offal meat under different packaging methods during storage at $4^{\circ} \mathrm{C}$. Indian J. Meat Sci.,6:46-53.

Muthulakshmi, M., Muthukumar, M., Rajkumar, R.S., Girish P.S. and Mooventhan, P. 2015. International Journal of Science, Environment and Technology. 4: $33-39$.

Shapton, D. A. and N. F. Shapton. 1991. Principles and Practices for the Safe Processing of Foods. ButterworthHeineman Ltd., Oxford, pp. 377-444.

\section{How to cite this article:}

Bhaskar Kanchi, Anitha Reddy Nalla, Naveen Kumar Reddy Metla, Shashi Kumar Manyam and Kesava Rao Vadapu. 2017. Effect of Different Packaging Conditions on Shelf Life of Chicken Samosa Stored at Refrigeration Temperature. Int.J.Curr.Microbiol.App.Sci. 6(5): 2432-2437. doi: https://doi.org/10.20546/ijcmas.2017.605.272 